\title{
The wave towards a new steady state: effects of earthworm invasion on soil microbial functions
}

\author{
Nico Eisenhauer · Jiří Schlaghamerský • \\ Peter B. Reich • Lee E. Frelich
}

Received: 16 March 2011/Accepted: 25 June 2011/Published online: 6 July 2011

(C) Springer Science+Business Media B.V. 2011

\begin{abstract}
Earthworms are ecosystem engineers that cause a long cascade of ecological effects when they invade previously earthworm-free forests. However, the consequences of earthworm invasion for soil microbial functions are poorly understood. Here, we used two well-studied invasion fronts of European earthworms in northern North American hardwood forests previously devoid of earthworms in order to investigate three stages of earthworm invasion: uninvaded, the front of the leading edge of earthworm invasion and locations invaded at least 10 years previously. Soil microbial biomass, respiration and metabolic quotient were measured. Earthworms had marked effects on soil microbial biomass $(-42 \%)$ and respiration $(-32 \%)$. At both sites, impacts were most pronounced at the leading edge of the invasion front, significantly decreasing soil microbial $\mathrm{C}$ use efficiency. This was most likely due to the disturbance of the soil microbial community caused by water stress. Based on these results, we hypothesize that effects of earthworm invasion on native soil
\end{abstract}

N. Eisenhauer $(\bowtie) \cdot$ J. Schlaghamerský .

P. B. Reich · L. E. Frelich

Department of Forest Resources, University of Minnesota, 1530 Cleveland Avenue N., St. Paul, MN 55108, USA

e-mail: nico.eisenhauer@web.de

J. Schlaghamerský

Department of Zoology and Ecology, Faculty of Science, Masaryk University, Kotlářská 2, 61137 Brno,

Czech Republic ecosystem functioning are most pronounced at the peak of the invasion wave. After experiencing this wave, ecosystems possibly enter a new steady state with altered biotic compositions and functions.

Keywords Ecosystem change - Exotic earthworms · Forest floor $\cdot$ Microbial biomass $\cdot$ Microbial respiration $\cdot$ Northern hardwood forests

\section{Introduction}

Anthropogenic biotic exchange threatens biodiversity and can compromise the functioning of ecosystems (e.g. Sala et al. 2000). Despite a considerable bias in favour of attention to aboveground invasions, the spread of exotic earthworms has received increasing notice in the last two decades (Bohlen et al. 2004; Hendrix et al. 2008). Earthworms are ecosystem engineers that cause a long cascade of ecological effects when they invade previously earthworm-free forests, including changes in soil nutrient status, soil bulk density, soil microbial processes, and reduction of native plant and soil microarthropod species richness (Frelich et al. 2006; Eisenhauer et al. 2007; Hendrix et al. 2008). The notable impacts of exotic earthworms on the nutrient cycling and functioning of native ecosystems (Burtelow et al. 1998; Bohlen et al. 2004; Groffman et al. 2004) have evoked concern about the consequences for carbon dynamics (Eisenhauer et al. 2007; Huang et al. 2010). Although understanding of 
effects of exotic earthworms on microbial community composition and activity is crucial for predicting future changes in carbon and nutrient dynamics (Huang et al. 2010), this topic has been insufficiently explored. Exotic earthworms have been shown to either decrease (e.g. Eisenhauer et al. 2007) or increase (e.g. Li et al. 2002) soil microbial biomass and activity. Reviewing the previous literature on exotic earthworm effects on soil microbes, McLean et al. (2006) concluded that earthworms change microbial community composition towards a smaller, but more active microbial community. They moreover hypothesized that impacts of exotic earthworms on soil microbes depend on the stage of invasion: initial decreases in soil microbial respiration and metabolic quotient may be followed by a decrease in microbial $\mathrm{C}$ use efficiency. Similarly, Straube et al. (2009) found nonlinear effects of exotic earthworms on soil microbial biomass and microarthropods, reinforcing the need for long-term studies. They posited a wavelike invasion pattern with most severe impacts in newly invaded habitats.

Here, we investigate two well-studied invasion fronts of European earthworms in northern hardwood forests in North America previously devoid of earthworms (Hale et al. 2005; Holdsworth et al. 2007). Transects perpendicular to the leading edges of earthworm invasion allowed us to discriminate between three invasion stages: uninvaded, the front of the leading edge, and invaded. Soil microbial biomass, respiration and metabolic quotient were determined as proxy measures for soil microbial functioning. In accordance with McLean et al. (2006) and Straube et al. (2009), we expected earthworm effects to be most pronounced at the leading edge of earthworm invasion.

\section{Materials and methods}

The two sites were located $250 \mathrm{~km}$ apart in northern Minnesota (Chippewa National Forest) and Wisconsin (Chequamegon section of Chequamegon-Nicolet National Forest), USA, a region devoid of native earthworms. Both study sites were covered with mesic forests approximately 80-100 years old after logging in the early 1900s, and were dominated by sugar maple (Acer saccharum) on deep, well drained, light colored sandy loams (Eutroboralfs on the Minnesota site and Fragiorthods and Haplorthods in
Wisconsin). The climate is humid continental, cold temperate: annual precipitation 650 and $870 \mathrm{~mm}$, mean January and July temperatures -15 and $+20^{\circ} \mathrm{C}$ and -12 and $+20^{\circ} \mathrm{C}$ at the Minnesota and Wisconsin sites, respectively. The two study sites were used in previously published studies of European earthworm invasion impacts on native plant community structure, and were chosen to include the leading edge of earthworm invasion (Hale et al. 2005, 2006; Holdsworth et al. 2007). At the Minnesota site (on the Ottertail peninsula at Leach Lake, named "Section 19") three parallel transects $10 \mathrm{~m}$ apart and $150 \mathrm{~m}$ in length, had been placed perpendicular to the leading edge of earthworm invasion in 1999 (Hale et al. 2005). For the present study, one of these transects was used. As the visible leading edge of earthworm invasion had further advanced, the transect was extended to a total length of $390 \mathrm{~m}$ (at 443-449 $\mathrm{m}$ a.s.l.; front of leading edge at $\left.47^{\circ} 16^{\prime} 0.00^{\prime} \mathrm{N}, 94^{\circ} 23^{\prime} 48.60^{\prime \prime} \mathrm{W}\right)$. At the Wisconsin site (at Tower Lake in the Rainbow Lake Wilderness Area) one transect of $400 \mathrm{~m}$ length had been placed in 2001 (Holdsworth et al. 2007). As the state of the litter layer indicated that at least the epigeic earthworm species Dendrobaena octaedra had penetrated substantially farther into the forest stand, the transect was extended to a total length of $700 \mathrm{~m}$ for the present study (at 380-405 $\mathrm{m}$ a.s.l.; front of leading edge at $\left.46^{\circ} 26^{\prime} 3.06^{\prime} \mathrm{N}, 91^{\circ} 19^{\prime} 36.00^{\prime \prime} \mathrm{W}\right)$. According to Hale et al. (2005) and Holdsworth et al. (2007), areas with thick organic horizons and a light brown A horizon were characterized by no earthworms or a small biomass (ca. $1 \mathrm{~g} \mathrm{~m}^{-2}$ ash-free dry mass, AFDM) of D. octaedra, whereas the middle areas of the transects, near the visible front of the leading edge of invasion, with thin organic horizons, had a moderate biomass (ca. 1-3 $\mathrm{g} \mathrm{m}^{-2}$ AFDM) of Lumbricus rubellus, Aporrectodea spp., and Octolasion tyrtaeum, while heavily invaded areas (with organic horizons absent at mid-summer) and black A horizons were characterized by the presence of high earthworm biomass (ca. 3-5 $\mathrm{g} \mathrm{m}^{-2}$ AFDM) of Lumbricus terrestris, L. rubellus and Aporrectodea spp. The latter have been invaded at least 10 years previously.

The sites were sampled on September 24 (Minnesota) and October 3, 2010 (Wisconsin). Along the transects, three plots $(10 \mathrm{~m} \times 4 \mathrm{~m}$ oriented perpendicular to the transect) were sampled, representing virtually uninvaded, front of the leading edge of 
invasion, and heavily invaded areas. The structure of the upper soil horizons and earthworm presence in larger soil cores taken in parallel within these plots (to sample mesofauna) confirmed our expectations concerning the stage of earthworm invasion. For the present study, 12 randomly situated soil cores were taken per plot to a depth of ca. $9 \mathrm{~cm}$ using a steel corer, including organic layers $(2 \mathrm{~cm}$ diameter, $3.14 \mathrm{~cm}^{2}$ surface area). The thickness of different soil layers varied between the three stages of invasion with thin organic layers at invaded locations. Each soil core (72 in total; 2 sites $\times 3$ stages of invasion $\times 12$ replicates) was stored separately in a closed plastic bag, transported to the laboratory, sieved $(<2 \mathrm{~mm})$ and stored frozen at $-20^{\circ} \mathrm{C}$ until further processing. Microbial biomass $\left[\mu \mathrm{g} \mathrm{C} \mathrm{mic}_{\mathrm{m}} \mathrm{g}^{-1}\right.$ soil dry weight], basal respiration $\left[\mu l \mathrm{O}_{2} \mathrm{~h}^{-1} \mathrm{~g}^{-1}\right.$ soil $\mathrm{dw}$ ], and metabolic quotient $\left[\mu \mathrm{O}_{2} \mathrm{~h}^{-1} \mathrm{mg}^{-1} \mathrm{C}_{\text {mic }}\right.$ ] were measured using an $\mathrm{O}_{2}$ microcompensation apparatus (Anderson and Domsch 1978; Scheu 1992). Microbial respiration was measured at hourly intervals for $20 \mathrm{~h}$ at $22^{\circ} \mathrm{C}$. Basal respiration was determined without addition of substrate; $\mathrm{C}_{\text {mic }}$ was calculated from the respiratory response to D-glucose (substrate-induced respiration method; Anderson and Domsch 1978). The average of the lowest three readings within the first $10 \mathrm{~h}$ was taken as "maximum initial respiratory response", (MIRR) and $\mathrm{C}_{\text {mic }}$ was calculated as $38 \times \operatorname{MIRR}\left(\mu \mathrm{l} \mathrm{O}_{2} \mathrm{~h}^{-1} \mathrm{~g}^{-1}\right.$ soil $\mathrm{dw}$; Beck et al. 1997). Glucose was added in appropriate amounts to saturate the catabolic enzymes of the microorganisms (20 $\mathrm{mg} \mathrm{g}^{-1}$ soil dw). Despite some criticism (Wardle and Ghani 1995), the metabolic quotient is regarded as an indicator of change in microbial metabolism in response to disturbance, i.e. microbial $\mathrm{C}$ use efficiency (Anderson and Domsch 1985). Gravimetric soil water content was determined for each sample by comparing soil fresh and dry weight ([\%]; dried for 3 days at $70^{\circ} \mathrm{C}$ ).

Effects of site and stage of earthworm invasion (uninvaded, leading edge, invaded) on soil microbial biomass, basal respiration, metabolic quotient and gravimetric soil water content were analyzed by twofactorial Analysis of Variance (ANOVA). Data on gravimetric soil water content were arc-sin-transformed to meet the requirements of ANOVA (normality and homoscedasticity of errors). Means ( \pm SD) presented in text and figures were calculated using non-transformed data. Means were compared using
Tukey's HSD test $(\alpha=0.05)$. Additionally, regressions were performed between soil microbial functions and soil water content. All analyses were performed using STATISTICA 7 (Statsoft).

\section{Results}

Microbial biomass $\left(759.6 \pm 348.6 \mu \mathrm{g} \mathrm{C}_{\text {mic }} \mathrm{g}^{-1}\right.$ soil $\mathrm{dw}$ ) was significantly affected by earthworm invasion status: microbial biomass was higher at uninvaded locations than at invaded locations $(+57 \%)$ and at the leading edge of earthworm invasion $(+89 \%$; $\left.\mathrm{F}_{2,62}=23.11, P<0.001\right)$. This pattern was more pronounced at the Minnesota site, resulting in a significant interaction between site and invasion stage $\left(\mathrm{F}_{2,62}=3.18, P=0.048\right.$; Fig. 1a). Basal respiration $\left(2.97 \pm 1.28 \mu \mathrm{l} \mathrm{O}_{2} \mathrm{~h}^{-1} \mathrm{~g}^{-1}\right.$ soil $\left.\mathrm{dw}\right)$ was significantly higher at uninvaded locations than at invaded locations $(+48 \%)$ and at the leading edge of earthworm invasion $\left(+54 \% ; \mathrm{F}_{2,62}=10.10, P<0.001\right)$. This pattern was consistent in both forests (invasion stage $\times$ forest: $\mathrm{F}_{2,62}=0.44, P=0.65$ ), though only significant at the Minnesota site (Fig. 1b). The metabolic quotient $\left(4.12 \pm 1.12 \mu \mathrm{O}_{2} \mathrm{~h}^{-1} \mathrm{mg}^{-1}\right.$ $\mathrm{C}_{\text {mic }}$ ) was significantly higher at the leading edge of earthworm invasion than in uninvaded $(+20 \%)$ and invaded areas $\left(+16 \% ; \mathrm{F}_{2,62}=6.22, \quad P=0.003\right)$. Similar to basal respiration, this pattern was similar in both forests (invasion stage $\times$ forest: $F_{2,62}=1.52$, $P=0.22$ ), though only significant at the Minnesota site (Fig. 1c). Gravimetric soil water content was significantly higher at uninvaded $(+33 \%)$ and invaded locations $(+30 \%)$ than at the leading edge of earthworm invasion $\left(\mathrm{F}_{2,62}=17.63, P<0.001\right)$. This pattern was more pronounced at the Wisconsin site, resulting in a significant interaction between site and invasion stage $\left(\mathrm{F}_{2,62}=12.42, P<0.001\right)$. Gravimetric soil water content was positively correlated with soil microbial biomass $\left(R^{2}=0.41, P<0.001\right)$ and basal respiration $\left(R^{2}=0.12, P=0.005\right)$, while it was negatively correlated with the metabolic quotient $\left(R^{2}=0.29, P<0.001\right.$; Fig. 2).

\section{Discussion}

Our results confirm previous studies showing that exotic earthworms significantly change soil microbial 


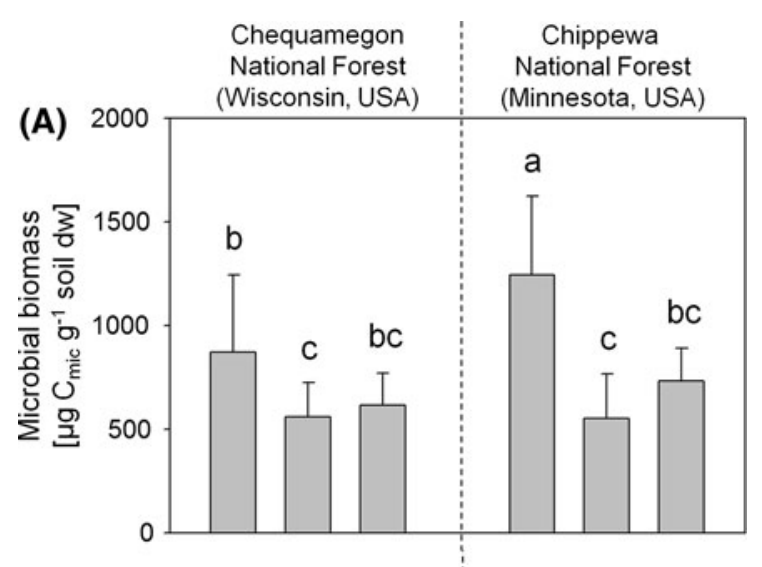

(B)
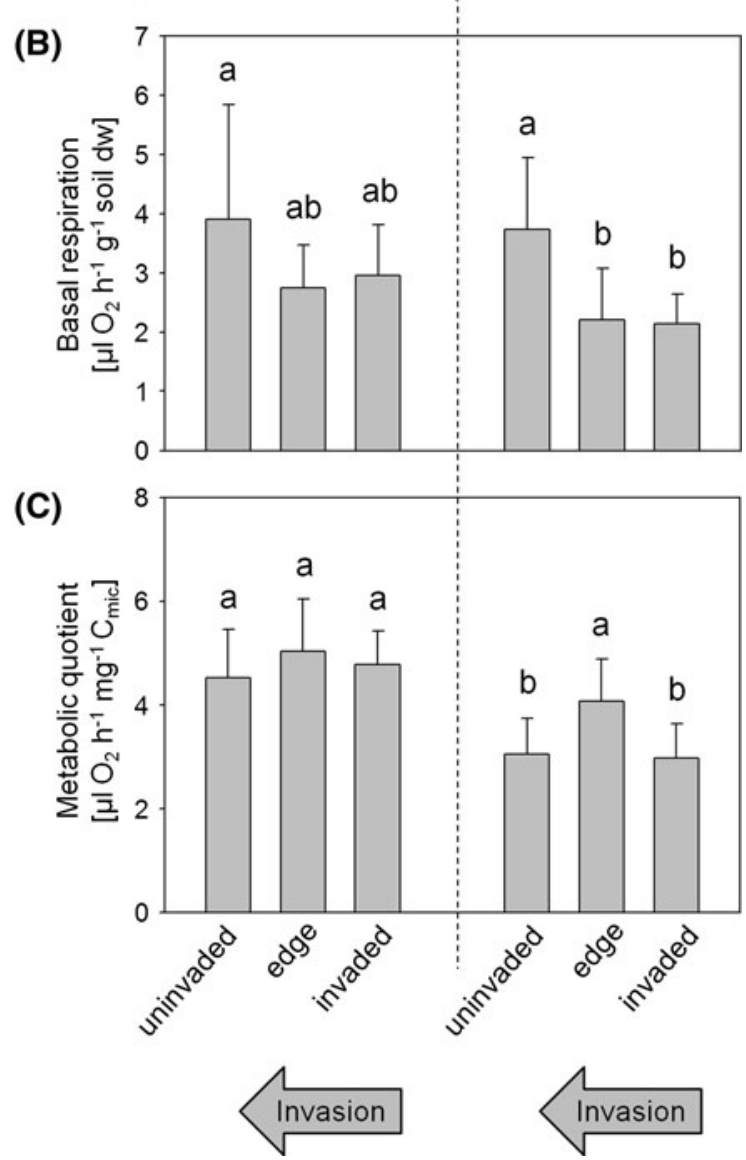

Fig. 1 Soil microbial biomass (a), basal respiration (b), and metabolic quotient (c) as affected by earthworm invasion (uninvaded, front of the leading edge of earthworm invasion, invaded) at the Wisconsin and Minnesota sites, respectively. Bars with varying letters differ significantly (Tukey's HSD test; $\alpha=0.05)$. Means with standard deviation

biomass and functions (Burtelow et al. 1998; Li et al. 2002; McLean et al. 2006; Eisenhauer et al. 2007). The present study moreover indicates that impacts are

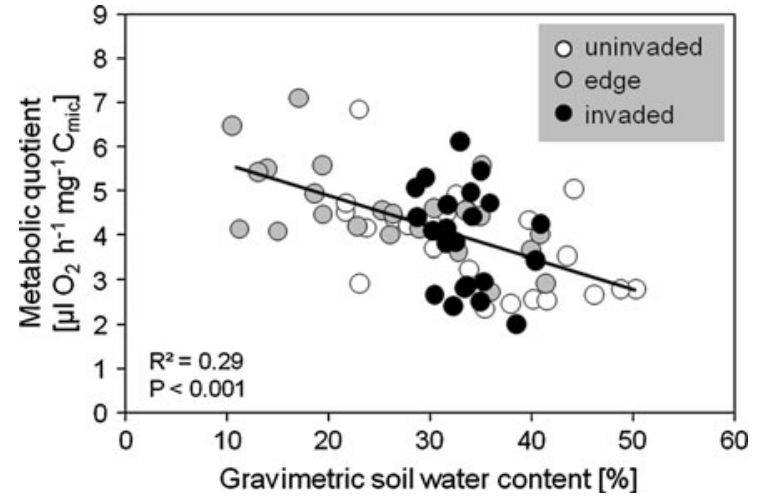

Fig. 2 Regression between gravimetric soil water content and metabolic quotient at the Minnesota and Wisconsin sites (pooled) differentiating locations without earthworms (uninvaded), the front of the leading edge (edge) and invaded locations (invaded)

most pronounced at the peak of the invasion wave, significantly decreasing soil microbial respiration and $\mathrm{C}$ use efficiency, and confirming our hypothesis. In line with the expectations of McLean et al. (2006), microbial biomass and respiration decreased significantly due to earthworm invasion. However, and in contrast to their expectations, the metabolic quotient was highest at the leading edge of earthworm invasion, suggesting disturbance of the soil microbial community, and declined at invaded locations to the level of uninvaded conditions. This pattern supports the findings of Eisenhauer et al. (2007) and Straube et al. (2009), showing the most pronounced impacts of invasive earthworms at the peak of the invasion wave. Although the metabolic quotient returned to the pre-invasion level at the invaded locations, the significant decrease in microbial biomass and respiration indicates a shift in microbial community composition. McLean et al. (2006) assumed a switch to a smaller, but more active microbial community, due to a decrease in the fungal:bacterial ratio. Earthworms may promote the dominance of more disturbance-resistant bacteria and reduce the biomass and diversity of fungi by disrupting hyphal networks of fungi (McLean et al. 2006). Bacteria have a lower $\mathrm{C}$ utilization efficiency than fungi, i.e. a higher metabolic quotient (Sakamoto and Oba 1994).

We found that the gravimetric soil water content was lowest at the leading edge of invasion, most likely due to soil compaction and burrow formation by earthworms (Hale et al. 2005). Earthworm burrows 
are known to function as preferential flow pathways for soil surface water and to change soil water holding capacity (Edwards and Bohlen 1996; Shipitalo et al. 2004). Particularly L. rubellus may have played a crucial role in affecting soil water content since this species characterized the leading edge of the invasion front. Since soil microorganisms strongly depend on the availability of water (e.g. Coleman et al. 2004), the decrease in soil water content may have represented a major disturbance. This was supported by a significant negative correlation between soil water content and the metabolic quotient in the present study. The fact that patterns were similar at both sites suggests that our findings may be general.

Moreover, exotic earthworms mix dead organic matter with mineral soil, thereby mostly decreasing soil microbial biomass in the upper soil layers but increasing it in lower soil layers (McLean et al. 2006), and are stronger competitors for organic material than microbes (Tiunov and Scheu 1999). Earthworm effects observed in the present study may be partly related to changes in the structure of the soil profile with a decreased thickness of organic layers at invaded locations (down to virtually bare mineral soil at the heavily invaded sites). However, impacts of earthworm invasion on soil microbes may be more complex, depending on environmental conditions (Huang et al. 2010) and the earthworm ecological groups involved (Eisenhauer 2010).

Further, earthworms are known to change herbaceous plant community composition (Gundale 2002; Gilliam 2006), favoring graminoids at the investigated sites (Hale et al. 2006; Holdsworth et al. 2007), which may indirectly alter soil microbial communities. The investigation of shifts in soil microbial structure due to direct and indirect effects of the invasion of different earthworm species is a promising research direction that would lead to a better understanding of long-term effects of earthworm invasion on soil microbial functions.

The results of this study suggest that effects of earthworm invasion on native ecosystem functioning are most pronounced at the peak of the invasion wave. After experiencing this wave, ecosystems may enter a new steady state with altered biotic compositions and functions.

Acknowledgments We thank Cindy Buschena, Montara Roberts and Susan Barrott (all University of Minnesota, USA) for their help during the processing of soil samples. Further, we thank Ingrid Kleinhans and Stefan Scheu (University of Göttingen, Germany) for their key role in this study by measuring soil microbial parameters. Comments of two reviewers helped to improve the paper. Nico Eisenhauer gratefully acknowledges funding by the Deutsche Forschungsgemeinschaft (DFG, German Research Foundation; Ei 862/1-1). Jiří Schlaghamerský gratefully acknowledges funding by the Ministry of Education, Youth and Sports of the Czech Republic (Research Plan MSM0021622416) and by the Fulbright Program (stating that neither the Government of the United States nor any agency representing it has endorsed the conclusions or approved the contents of this publication).

\section{References}

Anderson JM, Domsch KH (1978) A physiological method for the quantitative measurement of microbial biomass in soils. Soil Biol Biochem 10:215-221

Anderson T-H, Domsch KH (1985) Determination of ecophysiological maintenance carbon requirements of soil microorganisms in a dormant state. Biol Fertil Soils 1:81-89

Beck T, Joergensen RG, Kandeler E, Makeschin F, Nuss E, Oberholzer HR, Scheu S (1997) An inter-laboratory comparison of ten different ways of measuring soil microbial biomass C. Soil Biol Biochem 29:1023-1032

Bohlen PJ, Scheu S, Hale CM et al (2004) Non-native invasive earthworms as agents of change in northern temperate forests. Front Ecol Environ 2:427-435

Burtelow AE, Bohlen PJ, Groffman PM (1998) Influence of exotic earthworm invasion on soil organic matter, microbial biomass and denitrification potential in forest soils of the northeastern United States. Appl Soil Ecol 9:197-202

Coleman DC, Crossley DA Jr, Hendrix PF (2004) Fundamentals of soil ecology, 2nd edn. Elsevier Academic Press, San Diego

Edwards CA, Bohlen PJ (1996) Biology and ecology of earthworms. Chapman and Hall, London

Eisenhauer N (2010) The action of an animal ecosystem engineer: identification of the main mechanisms of earthworm impacts on soil microarthropods. Pedobiologia 53:343-352

Eisenhauer N, Partsch S, Parkinson D, Scheu S (2007) Invasion of a deciduous forest by earthworms: changes in soil chemistry, microflora, microarthropods and vegetation. Soil Biol Biochem 39:1099-1110

Frelich LE, Hale CM, Scheu S et al (2006) Earthworm invasion into previously earthworm-free temperate and boreal forests. Biol Invasions 8:1235-1245

Gilliam FS (2006) Response of the herbaceous layer of forest ecosystems to excess nitrogen deposition. J Ecol 94:1176-1191

Groffman PM, Bohlen PJ, Fisk MC, Fahey TJ (2004) Exotic earthworm invasion and microbial biomass in temperate forest soils. Ecosystems 7:45-54

Gundale MJ (2002) Influence of exotic earthworms on the soil organic horizon and the rare fern Botrychium mormo. Conserv Biol 16:1555-1561 
Hale CM, Frelich LE, Reich PB (2005) Effects of European earthworm invasion on soil characteristics in northern hardwood forests of Minnesota, USA. Ecosyst 8:911-927

Hale CM, Frelich LE, Reich PB (2006) Changes in hardwood forest understory plant communities in response to European earthworm invasions. Ecology 87:1637-1649

Hendrix PF, Callaham MA Jr, Drake JM et al (2008) Pandora's box contained bait: the global problem of introduced earthworms. Annu Rev Ecol Evol Syst 39:593-613

Holdsworth AR, Frelich LE, Reich PB (2007) Effects of earthworm invasion on plant species richness in northern hardwood forests. Conserv Biol 21:997-1008

Huang C-Y, Hendrix PF, Fahey TJ et al (2010) A simulation model to evaluate the impacts of invasive earthworms on soil carbon dynamics. Ecol Model 221:2447-2457

Li X, Fisk M, Fahey TJ, Bohlen PJ (2002) Influence of earthworm invasion on soil microbial biomass and activity in a northern hardwood forest. Soil Biol Biochem 34:1929-1937

McLean MA, Migge-Kleian S, Parkinson D (2006) Earthworm invasions of ecosystems devoid of earthworms: effects on soil microbes. Biol Invasions 8:1257-1273
Sakamoto K, Oba Y (1994) Effect of fungal to bacterial biomass ratio on the relationship between $\mathrm{CO} 2$ evolution and total soil microbial biomass. Biol Fertil Soils 17:39-44

Sala OE, Chapin FS, Armesto JJ et al (2000) Global biodiversity scenarios for the year 2100. Science 287:1770-1774

Scheu S (1992) Automated measurement of the respiratory response of soil microcompartments: active microbial biomass in earthworm faeces. Soil Biol Biochem 24:1113-1118

Shipitalo MJ, Nuutinen V, Butt KR (2004) Interaction of earthworm burrows and cracks in a clayey, subsurfacedrained, soil. Appl Soil Ecol 26:209-217

Straube D, Johnson EA, Parkinson D et al (2009) Nonlinearity of effects of invasive ecosystem engineers on abiotic soil properties and soil biota. Oikos 118:885-896

Tiunov AV, Scheu S (1999) Microbial respiration, biomass, biovolume and nutrient status in burrow walls of Lumbricus terrestris L. (Lumbricidae). Soil Biol Biochem 31:2039-2048

Wardle DA, Ghani A (1995) A critique of the microbial metabolic quotient $\left(q \mathrm{CO}_{2}\right)$ as a bioindicator of disturbance and ecosystem development. Soil Biol Biochem 27:1601-1610 